\title{
Histochemical Demonstration of Oxidative Enzymes Associated with Carbohydrate Metabolism in Cerebellar Neurons Cultured in Vitro*
}

\author{
Seung-Up KIM（金 承 業） \\ Received August 6, 1966
}

In order to estimate the metabolic capacities of cultured neurons, it is considered to be important to elucidate the enzyme activity associated with carbohydrate metabolism, since the energy source of the metabolism and the function in the central nervous system depend almost exclusively on carbohydrate.

In recent years, the activities of oxidative enzymes in neurons have been briefly touched in some histochemical studies on the central nervous tissue cultured in vitro, the enzymes demonstrated were, however limited to succinate dehydrogenase (OGAWA and OKAMOTO 1962, FRI DE 1964), DPN and TPN diaphorases (YoNEZAWA et al. 1962), and in the works of OGAWA and OKAMOTO, and of FRIEDE there were misinterpretations of glial elements as neurons.

The present study was designed on neurons grown in culture to investigate the activities of various enzymes associated with carbohydrate metabolism and to elucidate their intracellular distributions using more recent histochemical techniques.

\section{Material and Methods}

Mateirals used were neurons grown in cultures of newborn kitten and mouse cerebellum. The method employed for culture was that appeared elsewhere (Окамото 1958, Mizuno, Kiм and Окамото 1962, Кім 1963, 1965). As it has been proved that glucose is an essential nutritional factor to maintain cell elements and to develop myelin (HILD 1957, Bor NSTEIN and Murray 1958, Murray et al. 1962, Yonezawa et al. 1962), the glucose content of the nutritional fluid used in culture was raised in a final concentration of $500 \mathrm{mg}$ per cent. The cultures grown for various periods up to 60 days were observed to ascertain the presence of neurons under the phase-optics and then histochemical techniques were applied on them (Fig. 1).

The oxidative enzymes whose activities were studied are as follows : NADH and NADPH tetrazolium reductases; succinate dehydrogenase; NAD-linked iso-citrate, malate, lactate and alpha-glycerophosphate dehydrogenases and NADP-linked glucose-6-phosphate dehydrogenase.

The histochemical techniques used were based on the methods described by SCHIFFE and VESCO (1963). The tetrazolium salt employed was nitro blue tetrazolium.

In order to demonstrate succinate dehydrogenase, lactate dehydrogenase and alphaglycerophosphate dehydrogenase activity $0.1 \mathrm{ml}$ of $1 \mathrm{mg} / \mathrm{ml}$ phenazine methosulfate was added as intermediator (OGAWA and SHINONAGA 1962). The controls incubated in the absence of substrates were always negative.

* This paper is dedicated to the memory of the late Prof. Masaji SEKI. 


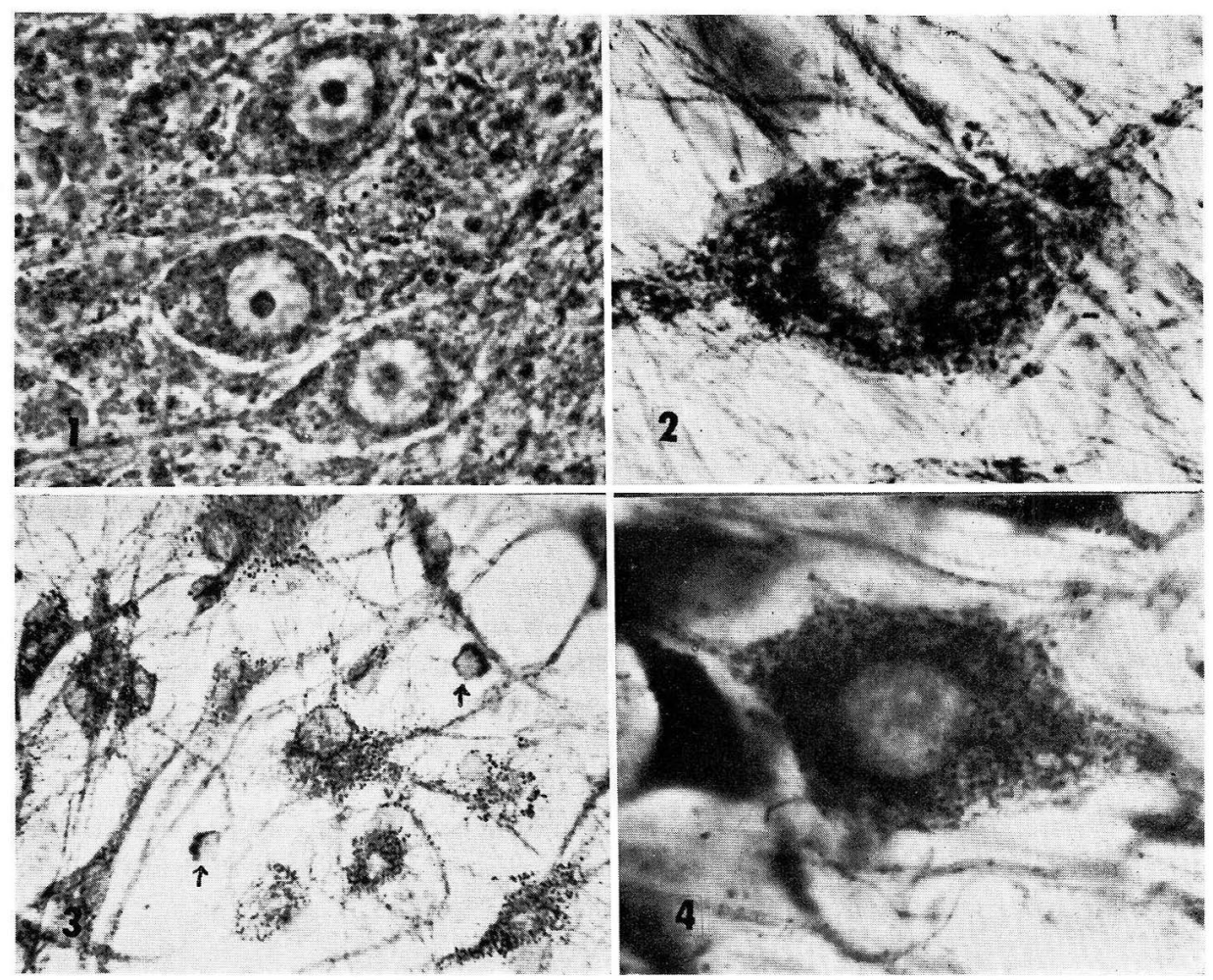

Fig. 1. Living neurons from 21 day old culture of newborn kitten cerebellar cortex. Note the vesicular nuclei and distinct nucleoli. Observation under the phase-optics. $\times 600$

Fig. 2. NADH tetrazolium reductase, 30 minutes incubation. A nerve cell from 24 day old culture of newborn kitten cerebellar cortex. Marked reactions are seen in neuronal soma and dendrites. $\times 1000$

Fig. 3. NADH tetrazolium reductase, 30 minutes incubation. The enzyme activity of the oligodendrocytes (arrows) is higher than the astrocytes in which the reactions are granular. The same culture as in Fig. $2 . \quad \times 400$

Fig. 4. NADPII tetrazolium reductase, 30 minutes incubation 20 day old culture (kitten). Note the granular enzyme activity in neuronal soma and dendrites. $\times 1000$

The representative cultures were also stained with Bodian's copper protargol silver technique and 0.1 per cent toluidine blue solution to determine the presence and the morphological features of neurons.

\section{Results}

$N A D H$ tetrazolium reductase: The reaction was shown as coarse formazan granules within neuronal soma and dendrites (Fig. 2). The reaction was also observed in axons in which the linear arrangement of granules was obvious. In the glial elements, appeared in culture, it was also revealed to be from moderate to strong enzyme activity.

The reaction of oligodendrocytes was higher than that of astrocytes in which the reaction was moderate and of fine granular nature (Fig. 3). The reactions of the other oxidative enzymes in glial elements showed almost the same tendency as in NADH tetrazolium reductase.

${ }_{N}$ ADPH tetrazolium reductase: The enzyme activity was similar to that of NADH. 

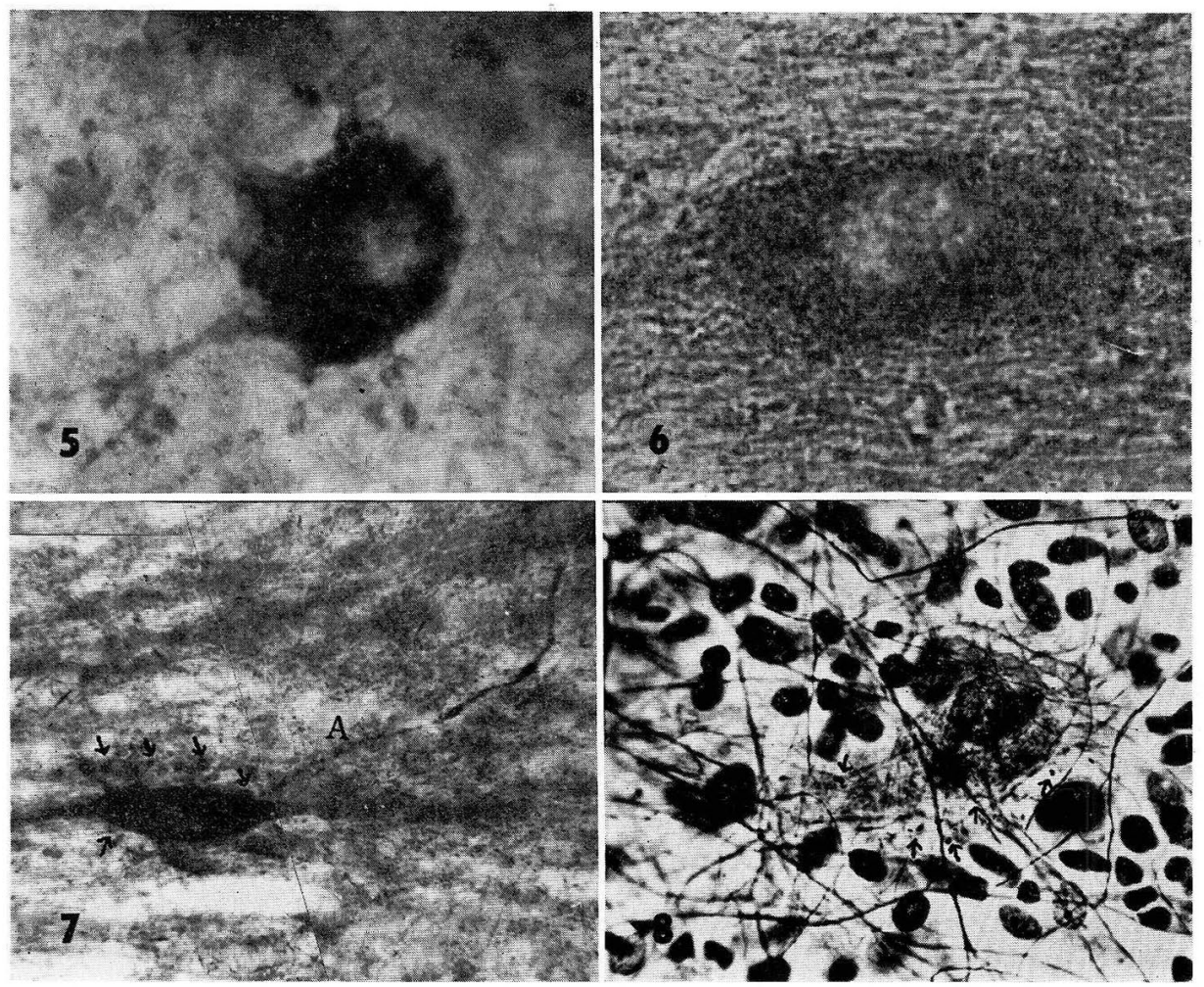

Fig. 5. Succinate dehydrogenase, 1 hour incubation. 52 day old culture (kitten). Note the intense deposits of formazan granules in neuronal soma and dendrites. $\quad \times 1000$

Fig. 6. Malate dehydrogenase, 1 hour incubation. 42 day old culture (kitten). The enzyme activity is revealed as fine formazan granules in neuronal soma. $\times 1000$

Fig. 7. Succinate dehydrogenase, 1 hour incubation. 18 day old culture (kitten). The spotted enzyme reactions are revealed along the surface of neuronal soma (arrows). The enzyme activity also appears in the axon (A). $\times 400$

Fig. 8. Bodian's silver impregnated culture. 22 day old culture (kitten). The ring-shaped terminal boutons are demonstrated along the surface of neuronal soma (arrows). $\times 400$

tetrazolium reductase. The reaction in formazan granules was revealed in neuronal soma and dendrites (Fig. 4).

Succinate dehydrogenase: Neurons revealed strong enzyme activity as shown by massive deposits of formazan granules throughout the soma and also in dendrites (Fig. 5). The reaction was also recognized in axon, and the spotted reactions along the surface of neuronal soma were occasionally observed which could be thought as the synaptic boutons (Fig. 7, arrows), since their distribution and size were highly similar with the synaptic boutons demonstrated in silver impregnated cultures (Fig. 8, arrows) (Кıм 1965).

Mala!e dehydrogen $s e:$ The enzyme activity was distributed throughout neuronal soma and dendrites as fine formazan granules (Fig. 6).

Iso-citrate dehydrogenase: The intenso enzyme activity was revealed as massive deposits of formazan granules within neuronal soma and dendrites (Fig. 9). 

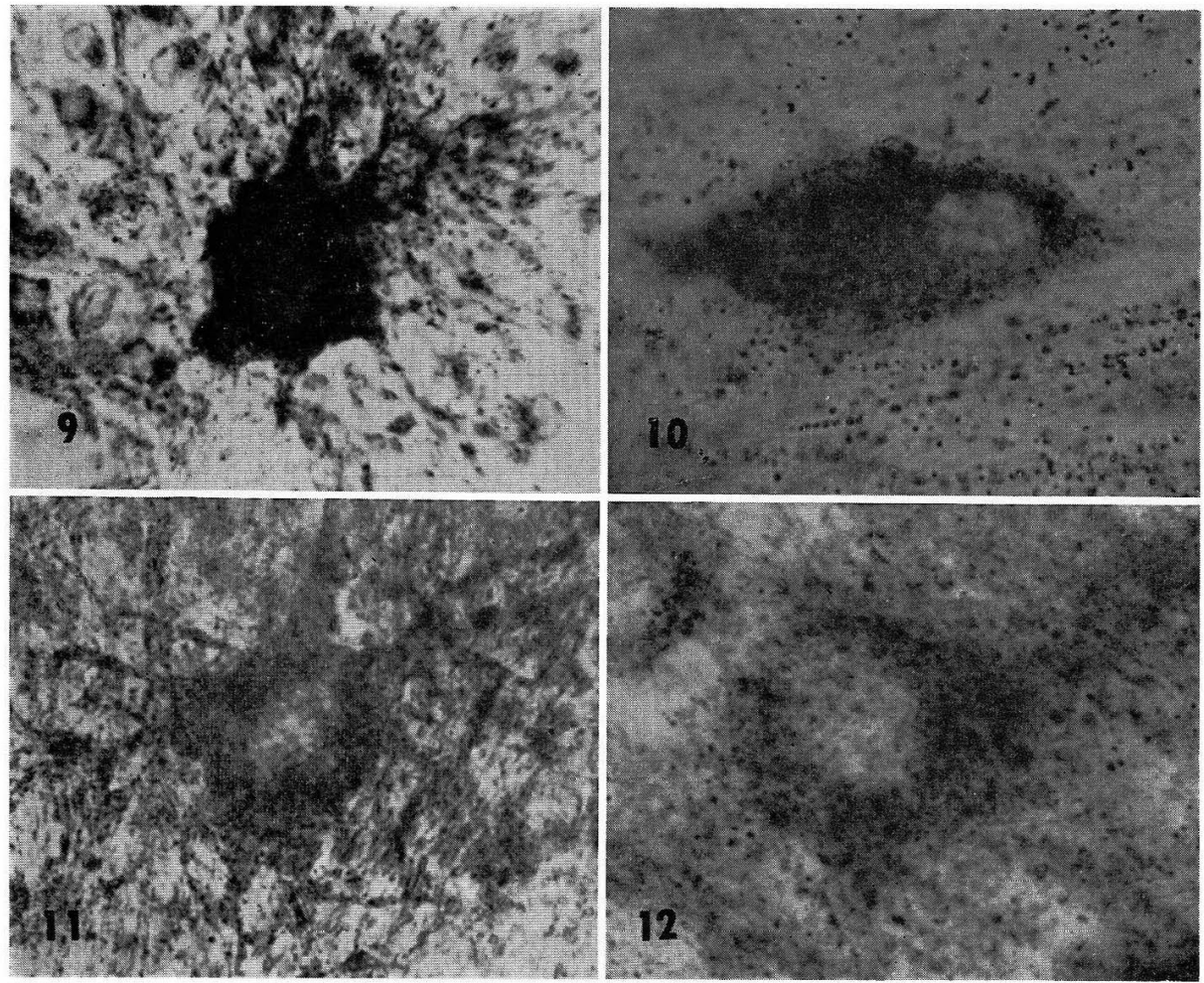

Fig. 9. Iso-citrate dehydrogenase, 1 hour incubation. 14 day old culture (mo'sse). Markel reacticn in deposits of formazan granules is demonstrated in neuronal soma and dencirites. $\times 1000$

Fig. 10. Lactate dehydrogenase, 2 hours incubation. 21 day olb culture (kitten). Note the intraneuronal formazan granules which indicate the enzyme activity. $\times 1000$

Fig. 11. Alpha-glycerophosphate dehydrogenase, 1 hour incubation. 30 day old culture (kitten). Note the enzyme activity positive formazan granules in neuronal soma and dendrites. $\times 1000$

Fig. 12. Glucose-6-phosphate dehydrogenase, 2 hours incubation. 20 day old culture (kitten). The enzyme activity is shown as formazan granules in neuronal soma and dendrites. $\times 1000$

Lactate dehydrogenase: The enzyme activity, as shown by the presence of formazan granules, was recognized within neuronal soma and dendrites (Fig. 10).

Alpha-glycerophosphate dehydrogenase: The positive reaction was shown as formazan granules throughout neuronal soma and dendrites (Fig. 11).

Glucose-6-phosphate dehydrogenase: The enzyme activity was distributed diffusely throughout the soma and dendrites as the blue formazan granules (Fig. 12).

\section{Discussion}

The present study was undertaken to demonstrate the activities of eight oxidative enzymes in cerebellar neurons cultured in vitro: the enzymes which are associated with carbohydrate metabolism. It is well accepted that the nervous tissue almost exclusively utilizes carbohydrate as a source of energy. And it is proved in tissue culture of nervous tissue that glucose is an essential nutritional factor to maintain cell elements and to develop myelin as it was described previously. 
Therefore it can be expected that neurons might be enzymatically well-equipped for the utilization of glucose to maintain their metabolism and function.

As the matter of fact, the results in the present study have revealed the high activity of oxidative enzymes associated with carbohydrate metabolism.

The strong activity of the following oxidative enzymes: 1) alpha-glycerophosphate dehydrogenase and lactate dehydrogenase, 2) malate dehydrogenase, iso-citrate dehydrogenase and succinate dehydrogenase, 3) glucose-6-phosphate dehydrogenase may indicate respectively the active performance of 1) glycolysis, 2) oxidation through the citric acid cycle and 3) oxidation through the hexosemonophosphate shunt. The strong reactivity of NADH and NADPH tetrazolium reductases is indicative of the overall activities of NAD- and NADP-linked dehydrogenases.

Thus the high activity of oxidative enzymes associated with carbohydrate metabolism may point to the possibility that glucose is the main fuel of neurons grown in culture.

The results of the present study, neurons grown in culture (Purkinje cells, cf. Kıм 1963) exhibit marked oxidative enzyme activity, are in good agreement with the previous studies on the demonstration of oxidative enzymes in the mammalian cerebellum performed on sections (Shimizu et al. 1957, succinate dehydrogenase; Thomas and Pearse 1961, DPN and TPN diaphorases, succinate, malate and iso-citrate dehydrogenases; TEWARI and Bourne 1962, succinate dehydrogenase; LAzALus et al. 1962, lactate and glucose-6-phosphate dehydrogenases; ShINONAGA 1965, succinate dehydrogenase).

On the discrepancy between the result of Thomas and Pearse (1961) and that of the present study on the enzyme activity of alpha-glycerophosphate dehydrogenase, further histochemical studies on sections and cultures are needed.

The spotted succinate dehydrogenase activity along the surface of neuronal soma seemed to show the enzyme activity of mitochondria of synaptic boutons (Fig. 7). This interpretation is supported by the previous studies on sections that the oxidative enzymes including succinate dehydrogenase were demonstrated in synaptic boutons along the surface of neuronal somas (Kumamoto and Bourne 1964, Nandy and Bourne 1964), and it is well correlated with the present author's previous observation that the distribution and the size of the spotted reactions were highly similar with synaptic boutons demonstrated in silver impregnated cultures (Fig. 8) (KIM 1965).

As shown in the present study, the application of histochemical methods to tissue culture of nervous tissue has some definite advantages: It is possible to investigate the precise localization of the enzyme activity in the flattened cell elements cultured in vitro, and to investigate dynamically the metabolism of neuronal and glial elements under experimental conditions by changing the constituents of the nutritional fluid. Thus the histochemical study of nervous tissue in culture would be a promising way to investigate the correlation of metabolism and structure of nervous system at the cell level,

\section{Summary}

In order to estimate the metabolic aspects of mammalian cerebel!ar neurons grown in culture, the activities of the following oxidative enzymes associated with carbohydrate metabolism were histochemically demonstrated: NADH tetrazolium reductase, NADPH tetrazolium reductase, succinate dehydrogenase, malate dehydrogenase, iso-citrate dehydrogenase, lactate dehydrogenase, alpha-glycerophosphate dehydrogenase and glucose-6-phosphate dehydrogenase.

The strong reactivity of oxidative enzymes investigated may be indicative of the active 
performance of glycolysis, oxidation through the citric acid cycle and oxidation through the hexosemonophosphate shunt in neurons grown in culture.

It is also shown that the histochemical methods to demonstrate the activity of various oxidative enzymes in sections can be applied with minor modification to nervous tissue cultured in vitro.

Grateful acknowledgements are made to Prof. М. Окамото for his constant interest and guidance, and to Dr. N. Mizuno for his helpful criticism in the present study.

\section{培養神経細胞における酸化酵素の組織化学的研究（内容自抄）}

組織培養下の哺乳動物小脳の神経細胞について，その代謝の様相を知るために炭水化物 代謝に関与する次の酸化酵素の活性を組織化学的に検索した。

$\mathrm{NADH}$-テトラゾリウム還元酵素, NADPH-テトラゾリウム還元酵菜， こはく酸脱水素酔 素, りんご酸脱水素酵素, イソくえん酸脱水素酵素, アルファーグリ七ロ燐酸脱水素酽素, グルコース-6-燐酸脱水素酵素.

培養神経細胞の各酸化醳素の活性が強陽性であることから, 神経細胞の解糖 (エムデン. マイエルホフ径路とワルブルグ-ディケンズ径路) およびトリカルボン酸回路の代謝が活発 であることが示唆された.

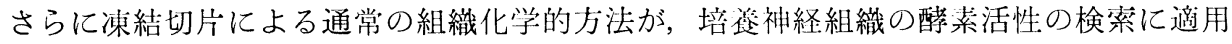
できることが判った。

\section{References}

Bornstein, M. B. and M. R. Murray : Serial observations on patterns of growth, myelin formation, maintenance and degeneration in cultures of new-born rat and kitten cerebellum. J. biophys. biochem. Cytol. $4: 499-504$ (1958).

Friede, R. L. : The enzymatic response of astrocytes to various ions in vitro. J. Cell Biol. 20:5-15 (1964).

Hild, W.: Myelinogenesis in cultures of mammalian central nervous tissue. Z. Zellforsch. 46:71-95 (1957).

Kim, S. : Neurons in the tissue culture. Arch. histol. jap. 23 : 401-429 (1963).

: Neurons in the tissue culture. Observations on terminal boutons in cultures of mammalian central nervous tissue. Ibid. $25: 371-386$ (1965).

Kumamoto, T. and G. H. Bourne : Histochemical evidence on localizat:on of succinic dehydrogenase in the synapse of the central nervous system of rabbit, rat and guinea-pig. Nature 204: 295-296 (1964).

Lazarus, S. S., B. J. Wallace, G. Edgar and B. W. Volk : Enzyme localization in rabbit cerebellum and effect of post mortem autolysis. J. Neurochem. $9: 227-232$ (1962).

Mizuno, N., S. Kim and M. Okamoto : Study on the embryonal granule cells of the cerebellum. Identification in the tissue culture. Arch. histol. jap. $23: 185-211$ (1962).

Murray, M. R., E. R. Peterson and R. P. Bunge : Some nutritional aspects of myelin sheath formation in cultures of central and peripheral nervous system. Proc. IV. Int. Congr. Neuropathol. 267-272 (1962).

Nandy, K. and G. H. Bourne : A histochemical study of the localization of the oxidative enzymes in the neurones of the spinal cord in rats. J. Anat. $98: 647-653$ (1964). 
Ogawa, K. and M. Okamoto : Histochemical demonstration of succinic dehydrogenase system in tissue culture. Texas Rep. biol. Med. 19 : 134-139 (1961).

Ogawa, K. and Y. Shinonaga: Role of intermediator in the tetrazolium histochemistry. Acta anat. nippon. 36: 550-560 (1961).

Okamoto, M. : Observations on neurons and neuroglia from the area of the reticular formation in tissue culture. Z. Zellforsch. $47: 269-28$ (1958).

Schiffer, D. and C. Vesco : Histochemical observations about the patterns of tetrazolium reduction, with different substrates, in glial cells of normal and pathological human nervous tissue. J. Histochem. Cytochem. 11 : 335-341 (1963).

Shimizu, N., N. Morikawa and Y. Ishii : Histochemical studies of succinic dehydrogenase and cytochrome oxidase of the rabbit brain, with special reference to the results in the paraventricular structures. J. comp. Neurol. $108: 1-2$ (1957).

Shinonaga, Y.: Histochemical and cytochemical studies on the succinic dehydrogenase in the developing cerebellum. Arch. histol. jap. 25 : 467-490 (1965).

Tewari, H. B. and G. H. Bourne : Histochemical studies on the distribution of oxidative enzymes in the cerebellum of the rat. J. Histochem. Cytochem. $10: 619-627$ (1962).

Thomas, E. and A. G. E. Pearse : The fine localization of dehydrogenases in the nervous system. Histochemie 2 : 266-282 (1961).

Yonezawa, T., M. B. Bornstein, E. R. Peterson and M. R. Murray : A histochemical study of oxidative enzymes in myelinating cultures of central and peirpheral nervous tissue. J. Neuropathol. exp. Neurol. 21 : 479-487 (1962). 